\title{
家族研究における公開ミクロデータの 利用・提供状況乙課題
}

\section{永井暁子}

\section{1. 公開ミクロデータによる 2 次分析の意義}

公開ミクロデータとは、政府統計やその他の社会調査のうち集計結果以外でも公開されている、つま り研究者などが共同利用可能なミクロ（匿名個票）デー夕をさす。欧米各国では一般的な研究方法とし てすでに確立されているこのような研究スタイルが、近年、日本の研究者の間で徐々に広がりつつある。

公開ミクロデータによる 2 次分析の意義について ${ }^{(1)} 、 2000$ 年 12 月に刊行された『社会調査の公開 データー2 次分析への招待』の序で、編者である佐藤博樹、石田浩、池田謙一の三氏は、政府統計以外 のいわゆる「社会調査」データについて、おおよそ以下のようにまとめている。第一に研究費の確保が 難しい若手研究者にとって有益である。第二に、データの収集過程が省略できるため課題設定・仮説構 築・仮説検証に集中することができる。第三に、複数の研究者が同じデータを再分析することにより、 研究者間の交流が活性化し、異なった仮説の成否の検討が可能となり、その結果、分析の厳密さやレべ ルの向上に寄与する。第四に、重複するテーマの社会調査が減少することで、研究資源の効率的な活用 が可能になり、また被対象者の調査負担も軽減される。第五に、時系列比較や国際比較の研究を行うこ とが容易になる。回答者の協力を最大限に生かすためにもデータを有効に利用すべきだという点、複数 の研究者による検証が可能となることで、分析結果の信頼性が高くなるという点は、今後、研究者間、 調査実施者間で広く共有されるべき認識であろう。

\section{2. データ・アーカイブの意義}

公開ミクロデータとして利用できるデータを収集、整備・提供、そしてその公開ミクロデータの存在 を研究者に知らせること自体に大きな役割を担っているのは、データ・アーカイブである。欧米では 1960 年代から設立され、その代表的なものがミシガン大学の ICPRS (Inter-university Consortium for Political and Social Research) である。アメリカ国内にもヨーロッパ諸国にも多くのデータ・アーカイブ が存在し、それらにはデータ・アーカイブのリンク集ともいえるサイトから簡単にアクセスできる。

日本の現状は、欧米に比べてほぼ 30 年遅れている。とはいえ、東京大学社会科学研究所付属日本社 会研究情報センターの SSJ データアーカイブ（Social Science Japan Data Archive）が 1998 年 4 月から民 間団体の研究者等の調査結果個票を収集し, データ提供を開始した。同時期に札幌学院大学社会情報学 部の社会・意識調査データベース作成プロジェクト（SORD：Social and Opinion Research Database Project）でも、インターネットを介したデータ提供が開始され、現在の研究環境は格段に進歩している。 


\section{3. 家族研究での公開ミクロデー夕利用傾向}

このような公開ミクロデータを用いた研究成果についてみてみよう。前揭の佐藤らは 2 次分析によ る研究に関する日本の実情を社会学評論を例として、1998 年には 25 本中 1 本 $(4 \%) 、 1999$ 年 29 本中 9 本（31\%：ただし、SSM（Social Stratification and Mobility）の特集を除くと、23 本中 3 本で 13\%)、 アメリカでは American Sociological Review を例として、1998 年 46 本中 28 本 (61\%) 1999 年 40 本中 27 本 $(68 \%)$ と数字をあげ、日米の公開ミクロデータ利用傾向には歷然とした差があるとしている (佐藤ほか, 2000, pp. 4-5)。

家族研究に目を向けてみるならば、Journal of Marriage and the Family の 1999 年から 2000 年に刊行さ れた 8 冊のうち、90 年代のまとめを特集として組んだ 2000 年 No. 4 を除いた 7 号分には、129 本の論 文が揭載され、その半数近くは公開ミクロデー夕を利用した研究である。公開ミクロデータとして最も 頻繁に利用されているのはウイスコンシン大学の L. Bumpass と J. Sweet を中心として開始され、現在 も継続して行われているパネル調査 NSFH（National Survey of Families and Households）であり、22 本 の論文で利用されている。そのほかに PSID (Panel Study of Income Dynamics)、NLS (National Longitudinal Survey)、GSS（General Social Survey）や政府統計など、多様なデータが利用されている。一方、 公開ミクロデータを用いていない実証研究では、大量調査ではとらえにくいものをテーマとしている傾 向があり、研究目的に照らして利用データの「椿み分け」がみられる。

『家族社会学研究』では第 10（2）号に加藤（1998）の NSFH を用いた論文が、第 11 号には末盛 （1999）の日本家族社会学会・全国家族調查研究会の NFR（National Family Research）予備調查を用い た論文が揭載された。今後 NFR 98 デー夕を利用した論文は増加すると思われるが、その他のデー夕を 利用した論文の揭載がどれほど增えるかは公開ミクロデー夕の質と量によるところが大きいであろう。

\section{4 、家族研究で利用可能な公開ミクロデー夕}

世界各国の公開ミクロデータに関しての詳細な情報は佐藤ほか（2000）、政府統計については松田ほ か（2000）に詳しく紹介されている。前掲の NSFH、PSID、NLS は同一個人を長期にわたって追跡す るパネル調査である。現在、世界各国でパネル調査が実施され、データが公開されている ${ }^{(2)}$ 。とくに NSFH は家族関係についての詳細な質問項目が含まれており、また、BHPS（British Household Panel Survey）は家族歷についての詳細な質問項目が含まれている。GSS は家族に関する態度や行動につい ての質問項目があり、世界各国で共通の調査項目を入れて実施されているので、国際比較などに有用で ある。

日本に関するデー夕で利用可能なデー夕の代表的なものはNFR 98 であり、今後広く公開される予定 である。NFR 98 の説明については、筆者はその立場にはなく、また日本家族社会学会大会やニュース レターで再三ふれられているので、このレポートで紹介するには及ばないだろう。

2001 年 1 月時点で SSJ データ・アーカイブには、直接提供しているもの、提供先の情報を揭載して いるものを含めると、302 件の公開ミクロデータが登録されており、そのうち家族研究と関連するもの として、次のデータがあげられる。

JGSS（日本版 General Social Surveys）は文字どおり前揭の GSS の日本版である。現在公開されてい 
るのは第 1 回・第 2 回予備調査データであり、2000 年には第 1 回の本調査が実施され、その後、公開 される予定である。このデー夕は全国規模の調査であるとともに、国際比較が可能なデータである。

日本家族社会学会・全国家族調査研究会の NFR 予備調査である「家族と夫婦関係に関する調査」は、 調査地は東京に限定されるが、前揭の NSFH を念頭において設計された点に特徵がある。

このほかに、生命保険文化センターの「家族の変化と生活設計に関する調査」「若者の生活意識に関 する調査」「女性の生活意識に関する調査」「夫婦の生活意識に関する調査」「老後生活と福祉サービス に関する調査」「高歯者介護に関する調査」「老後生活のリスクに関する調査」「生活保障に関する調 査」「生活保障と生命保険に関する調査」「核家族世帯における家計の現状」、連合総合開発研究所の 「小学生・中学生の生活に関するアンケート調査」「21 世紀ライフビジョン調査（組合員、奥様、カッ プリング)」「仕事と育児に関する調査」、国民生活金融公庫総合研究所の「就学生をもつ家庭の家計調 査」、全国大学生活協同組合連合会の「学生生活実態調査」日本労働研究機構の「職業と家庭生活に関 する全国調査（第 3 回職業移動と経歴調査）」メーワルト・ウルリッヒの「日本人の価值観に関する 研究」家計経済研究所の「消費生活に関するパネル調査」などがある。

SORD から公開されているデータは 12 件あり、そのうち家族研究と関連があるのは、小島秀夫の 「婦人の生活実態と意識に関する調査」、前揭のメーワルト・ウルリッヒの「日本人の価値意識に関する 研究」、日本家族社会学会・全国家族調査研究会の NFR 予備調査である「家族と夫婦関係に関する調 査」である。

\section{5. 公開ミクロデータに関する課題}

データ・アーカイブも設立され、徐々に日本の社会科学界にも進展が認められるが、いくつかの課題 を残している。

欧米諸国では 1970 年代から人口センサスや家計調査など多くのデータが、部分標本の抽出、個体識 別につながる属性情報の削除を行うなど、公開可能なように再加工のうえ公開され、研究者によって分 析されてきた。日本の政府統計に関しての匿名個票データの研究者への公開については、「統計行政の 新中・長期構想」によって、ようやく重い扉が開きかけてきたというのが現状である ${ }^{(3)}$ 。最近では、松 田編（1999）や国立社会保障・人口問題研究所編（2000）のように、政府統計の匿名個票データを指定統 計の目的外使用の規則に基づいて利用した論文集が刊行され、政府統計の原データを再加工したもので あってもそれを利用した意義が示されている。政府統計ミクロデータは、たとえ $1 / 5 、 1 / 10$ の再抽出 データであっても通常の社会調査とは比較にならない規模であり、これを使いこなすには、今後より広 い範囲でのデータ公開と政府統計データ利用にあたっての研究者側の知識の蓄積が必要とされるだろう。 次に、公開つまり共同利用を目的とした調査と、調査実施後にデータ・アーカイブに寄託される調査 との差異についてである。調査実施後にデータが奇託されることは 1 章で示したように、大変有意義 なことである。一方、共同利用を目的として調査を実施する場合には、調査の設計についても考慮しな ければならないだろう。

最後に、公開を目的とした調査実施の難しさについて述べたい。その原因の一部分は、財源確保の困 難と公開データ作成を主要業務とした機関・職員の少なさにある。たとえば、JMF で利用されていた 
公開ミクロデー夕の財源確保の条件は、いかに多くのユーザーをもつかということにかかっている。ま た、調査を継続することが調査機関の維持や若手研究者の就職に影響している。そのため、精度の高い 調査を目指し、また、ユーザーサービスに努めるというモチベーションにつながる。このような価値観 は日本ではほとんどなく、よりよい分析結果を出すことが目的とされている。したがって、日本でより よい公開ミクロデータの作成を目指すことには、調査を担当する研究者にかなりの消耗感を生じされる。 これは、公開を目的とした調査を実施する社会基盤がないということに収斂する。さらにつけ加えるな らば、海外の公開ミクロデータのなかで利用率の高い調査はパネル調査であった。しかし、パネル調査 の実施は、財源の確保がさらに困難であり、それについては諸外国も同様である。

匿名個票データの公開についての意義、とくに回答者のプライバシー保護 ${ }^{(4)}$ を基本的な条件におき ながらも、回答者の協力を最大限に活かすという認識の共有、そして公開・共同利用を目的とした調査 実施のための社会基盤の整備が今後必要である。

\section{注}

（1）2次分析についての佐藤ほか（2000）以外の参考文献としては、正岡・嶋崎（1999）、嶋崎 （2001）などがあげられる。また、公開ミクロデータの 2 次分析を用いることについてのメリット・ デメリット、とくに社会調査論などの授業の場面で用いることへのメリット・デメリットについての 議論は、SSJ データアーカイブによる第 4 回公開セミナーやSORD の 1998 年度、1997 年度ワーク ショップなどで議論されている。

（2）世界各国のパネル調査の情報は『家計経済研究』に揭載する予定である（永井ほか, 2001）。この レポートは、2000 年 10 月 $28 ・ 29$ 日にミシガン大学において、HRS (Health and Retirement Study)、 NLS、PSID、ISR（University of Michigan Institute for Social Research）のサポートのもとに開催され た「パネル調査機関のインターナショナル・ワークショップ」の資料をもとに作成した。会議には BHPS (British Household Panel Study)、PSELL (Panel Socio-Economique' Liewen zu Lëtzeburg')、 HRS、HILDA (Household, Income, and Labour Dynamics on Austraria)、JPSC (Japanese Panel Survey on Consumers)、KLIPS (Korea Labor and Income Panel Study)、MxFLS (Mexican Family Life Survey)、 MHAS (Mexican Health and Aging Study)、PSFD (Panel Study of Family Dynamics : 台湾)、PSID、 GSOEP (German Socio Economic Panel)、HUS (The Swedish Panel Study of Household Market and Nonmarket Activities)、SLID (Survey of Labour and Income Dynamics : カナダ)、IFLS (Indonesia Family Life Survey)、NLS の代表が参加し、おもに調査の技術的な問題が議論された。これらのパネ ル調査データは公開されている、あるいは公開が予定されている。また、家族研究にも有用なデー夕 が多い。BHPSについては、Berthoud and Gershuny eds.（2000）を参照のこと。パネルデータの特質、 紹介、分析方法については、Rose eds.（2000）に詳しい。

（3）この問題については 1995 年以前からも議論されているが、研究領域への活用という点で具体性を 帯びてきたのは、1995 年の統計審査議会答申「統計行政の新中・長期構想」からである。松田 （1996）、北田（1998）、松田（1999）、松田ほか（2000）などの論文では、他の国が政府統計を公開 するに至った経緯を含めて、政府統計の研究利用について論じられている。文部省科学研究費特定領 
域研究のミクロ統計利用については、下記、日本経済統計情報センターのホームページを参照のこと。 （4）「匿名性」概念とそのための措置についての議論は、松田ほか（2000）にまとめられている。

\section{参考文献}

石原邦雄, 1995，「全国規模の家族生活総合調査と公開利用データの作成一ウィスコンシン大学 NSFH

調査の場合」, 東京都立大学『人文学報』261, 219-244.

石原邦雄編, 1997, 『重点領域研究「ミクロ統計データ」公募研究（課題番号 08209118）、「家族構造の

国際比較のための基礎的研究一公共利用ミクロデー夕の作成と活用」, 平成 8 年度報告書 (1), 公

共利用ミクロデータの活用による家族構造の国際比較研究一米国 NSFH データの利用を通して』.

石原邦雄編, 1997，『重点領域研究「ミクロ統計デー夕」・公募研究（課題番号 08209118）「家族構造の

国際比較のための基礎的研究一公共利用ミクロデータの作成と活用」平成 8 年度報告書（2）公共

利用をめざす家族構造の基礎的研究ミクロデータの作成一「家族と夫婦に関する調査」第 1 次報

告書』(改訂版は 1998 年に刊行).

石原邦雄編, 1998, 『重点領域研究「ミクロ統計デー夕」・公募研究（課題番号 08209118）「家族構造の

国際比較のための基礎的研究一公共利用ミクロデータの作成と活用」平成 9 年度報告書（3）家族

構造の国際比較研究をめざして一米国 NSFH データの利用を通して（第 2 次報告）』.

石原邦雄編, 1999, 『重点領域研究「ミクロ統計デー夕」・公募研究（課題番号 10113107）「家族構造の

国際比較のための基礎的研究一公共利用ミクロデータの作成と活用」平成 10 年度報告書（1）ミ

クロデータの活用による米国家族の分析一日米比較の視点から』.

石井クンツ昌子, 1998,「米国における家族世帯全国調査データの公開とその利用」, 財団法人日本統計

協会編『統計』8, 25-28.

加藤彰彦, 1998,「夫婦形成夕イミングに対する定位家族構造の効果とそのコーホート間変動一NSFH

デー夕にみる米国家族変動の一側面」, 日本家族社会学会編『家族社会学研究』10(2), 111-127.

北田祐幸, 1998，「我が国のミクロデー夕活用の現状と課題」, 財団法人日本統計協会編『統計』8, 33-36. 国立社会保障・人口問題研究所編, 2000, 『家族・世帯の変容と生活保障機能』東京大学出版会.

正岡寛司, 嶋崎尚子, 2000, 『近代社会と人生経験』放送大学教育振興会.

松田芳郎, 1996,「ミクロ・データ活用の社会的基盤」, 財団法人日本統計協会編『統計』 2 月号, 1-7. 松田芳郎, 1999, 『ミクロ統計データの描く社会経済像』日本評論社.

松田芳郎編, 1999, 『統計情報活用のフロンテイアの拡大一ミクロデータによる社会構造解析』統計情

報研究開発センター。

松田芳郎, 濱砂敬郎, 森博美編, 2000, 『講座ミクロ統計分析 第 1 巻 統計調査制度とミクロ統計の開

示』日本評論社.

松田芳郎, 寺崎康博, 舟岡史雄編, 『講座ミクロ統計分析 第 5 巻 家族と世帯のミクロデータ分析』日

本評論社. (刊行予定時期未定).

永井暁子・溝口由己・樋口美雄・チャールズ・ユウジ・ホリオカ, 2001, 「世界のパネル調査一ミシガ

ン・パネル調査会議から」, 財団法人家計経済研究所編『家計経済研究』通巻 50 号, (頁未定). 
日本家族社会学会・全国家族調査（NFR）研究会編, 1998, 『夫婦・親子関係の測定と方法：NFR 予備 調査データを用いた検討』.

日本家族社会学会・全国家族調査（NFR）研究会編, 1998, 『家族調査質問項目インベントリーー全国 家族調査に向けて』.

日本家族社会学会・全国家族調査（NFR）研究会編, 2000, 『家族生活についての全国調査（NFR 98）

NO. 1』.

日本統計協会編, 1998,「テーマ：海外におけるミクロデータの提供とその利用」『統計』8月号, 1-36. 大阪商業大学比較地域研究所・東京大学社会科学研究所, 2000, 『文部省指定学術フロンティア推進拠 点研究プロジェクト日本版 General Social Surveys (JGSS) 第 1 回予備調査基礎集計表・コード ブック』.

大阪商業大学比較地域研究所・東京大学社会科学研究所編, 2001, 『文部省指定学術フロンティア推進 拠点研究プロジェクト日本版 General Social Surveys (JGSS) 第 2 回予備調査基礎集計表・コード ブック』

佐藤博樹・石田浩・池田謙一編, 2000, 『社会調査の公開データー2 次分析への招待』, 東京大学出版会. 嶋崎尚子, 2001,「社会学における 2 次分析の方法と可能性」, 早稲田社会学会編『社会学年誌』42（頁 未定).

SSJ データ・アーカイブ東京大学社会科学研究所付属日本社会研究情報センター, 2000, 『SSJ データ・ アーカイブ第 4 回公開セミナーーSSJ データアーカイブを利用した研究成果及び公開データを利用 した研究と教育のあり方 : データ・アーカイブと 2 次分析』

末盛慶, 1999,「夫の家事遂行および情緒的サポートと妻の夫婦関係満足感一妻の性別役割意識による 交互作用」, 家族社会学会編『家族社会学研究』11,71-82.

R. Berthoud and J. Gershuny eds., 2000, Seven Years in the Lives of British Families : Evidence on The Dynamics of Social Changes from British Household Panel Survey, The Policy Press.

D. Rose ed., 2000, Rcsearching Social and Economic Change : The Uses of Household Panel Studies, Routledge.

\section{関連サイト}

SSJ データアーカイブ http://ssjda.iss.u-tokyo.ac.jp/

社会・意識調査データベース（SORD） http://www.sgu.ac.jp/soc/sordhp/index.html

CESSDA（Council of European Social Science Data Archive）運営の世界各国のデータ・アーカイブへの

リンク集 http://www.nsd.uib.no/Cessda/europe.html

日本経済統計情報センター http://docjes.ier.hit-u.ac.jp/page01.htm

National Survey od families and Households（NSFH）ホームページ http://www.ssc.wisc.edu/nsfh/

日本版 General Social Surveys（JGSS）ホームページ http://www.jgss.daishodai.ac.jp/

消費生活に関するパネル調査（JPSC）ホームページｈttp://www.kakeiken.or.jp/panel.htm

(ながい あきこ・家計経済研究所) 